\title{
OCCURRENCE OF Fusarium SPECIES IN MAIZE GRAINS FOR SILAGE
}

\section{Krnjaja ${ }^{1}$ J. Lević ${ }^{2}$ S. Stanković ${ }^{2}$ Z. Bijelić ${ }^{1}$ V. Mandić ${ }^{1}$ Lj. Stojanović ${ }^{1}$}

\author{
${ }^{1}$ Institute for Animal Husbandry, Autoput 16, P. Box 23, 11080, Belgrade-Zemun, Republic of Serbia \\ ${ }^{2}$ Maize Research Institute „Zemun Polje”, Slobodana Bajića 1, 11185, Belgrade-Zemun, Republic of \\ Serbia \\ Corresponding author: vesnakrnjaja.izs@gmail.com \\ Original scientific paper
}

\begin{abstract}
Grain samples of two maize hybrids, medium early (ZP434) and late maturity (ZP704), collected during harvest in 2008 were investigated for contamination by fungi. Grains were plated on agar media and grown fungi were identified by morphological macroscopic and microscopic characteristics on potato-dextrose agar (PDA) and synthetic nutrient agar (SNA). Species of the genus Fusarium were the most common in both hybrids, and their presence amounted to $33.89 \%$ (ZP434) and $42 \%$ (ZP704). Other fungi of genera, Acremonium, Alternaria, Aspergillus, Chaetomium, Cladosporium, Nigrospora, Penicillium, Rhizopus and Trichotecium, were isolated from 0 to $41 \%$. Four species belonging to the genus Fusarium were identified, of which the species $F$. verticillioides was the most common with $28.63 \%$ in ZP434 and $30.5 \%$ in ZP704 hybrids. The presence of $F$. graminearum, $F$. proliferatum and $F$. subglutinans ranged from 3\% (ZP704) to 5\% (ZP434), 0.13\% (ZP434) to 7\% (ZP704) and $0.13 \%$ (ZP434) to 7\% (ZP704), respectively. Generally, the incidence of every particular fungus was higher in the late maize hybrid with a higher moisture content than in the medium-early hybrid with a lower moisture content.
\end{abstract}

Key words: maize, silage, pathogenic fungi, Fusarium spp.

\section{Introduction}

Maize is one of the most important components of animal feed in Serbia. In animal feeding maize is used as whole grains, ground grain (bruised grain), in mixtures, as well as, silage from whole plants. Healthy grain of maize is a prerequisite for good reproduction and growth of animals.

Maize is cultivated on approximately $1.3 \mathrm{M}$ ha in Serbia (Statistički godišnjak Srbije, 2009). Grain of maize, as well as, of other cereals, is susceptible to infestation of numerous microorganisms. Fungi of the genera Fusarium, Alternaria 
and Cladosporium are predominantly active in fields, while fungi of Penicillium and Aspergillus act in storages (Scudamore, 1993). Potentially the most important fungal toxigenic species in Serbia belong to genera Fusarium, Penicillium and Aspergillus, and they are isolated mainly from maize and wheat, either as field crops or components of feed and food (Lević et al., 2004). F. graminearum Schwabe, F. verticillioides (Saccardo) Nirenberg (syn. F. moniliforme Sheldon) and F. subglutinans (Wollen. \& Renik.) Nelson, Toussoun \& Marasas, three very toxigenic fungal species of the genus Fusarium, are the most common pathogens in maize grain all over the world (White, 1999).

Food and feed safety and hygiene are a significant problem, and great attention is directed towards diseases that are closely related to different mycotoxicoses. Mycotoxins cause a whole range of disorders in the body of animals, ranging from biochemical changes, through the functional and morphological damages of different tissues and organs, to the appearance of clinical signs of mycotoxicoses with even possible lethal outcome (Jakić-Dimić et al., 2009).

Since the maize is in Serbia one of the most important components in the food chain, the aim of this study was to investigate the microbiological quality of grain used for silage. Special attention was devoted to determining toxigenic species such as the fungi of the genus Fusarium.

\section{Materials and Methods}

During September of 2008 the samples of maize grain that is used for silage were collected in the production plots of the Institute for Animal Husbandry in Belgrade-Zemun. The moisture content of samples was $16.3 \%$ in the medium early hybrid ZP434 (FAO 400) and 22.0\% in the late hybrid ZP704 (FAO 700). A total of 1200 grains, 800 of ZP434 and 400 of ZP704, were surface-sterilised with $1 \%$ solution of sodium hypochlorite, rinsed three times with distilled water, dried and then five seeds were distributed on the PDA in 100-mm Petri dish. The identification of fungi was carried out after seven days of incubation under laboratory conditions. on the basis of morphological macroscopic and microscopic characteristics on potato-dextrose agar (PDA) and synthetic nutrient agar (SNA). Determination of Fusarium species was done after Nelson et al. (1983) and Burgess et al. (1994), while remaining fungal genera were determined after Ellis (1971) and Watanabe (1994).

\section{Results}

Ten genera of pathogenic fungi were isolated from grains of examined hybrids, including Acremonium, Alternaria, Aspergillus, Chaetomium, Cladosporium, Fusarium, Nigrospora, Penicillium, Rhizopus and Trichotecium. Their presence 
varied from $0 \%$ to $42 \%$. Small number of grains of investigated hybrids were not contaminated with fungi (up to $0.38 \%$ ). The presence of the most common genus Fusarium in both examined hybrids amounted from $33.89 \%$ (ZP434) to $42 \%$ (ZP704), followed by the presence of Alternaria genus $(22.63 \%$ in ZP434 and $41 \%$ ZP704). Besides Fusarium and Alternaria, genera Acremonium and Nigrospora also were classlessness in the late maturity hybrid ZP704 (7.75\% and 2\%, respectively) compared to the medium early hybrid ZP434 $(0.13 \%$ and $0 \%$, respectively) (Table 1).

Table 1. Incidence (\%) of pathogenic fungi genera on grains in two maize hybrids

\begin{tabular}{|l|c|c|}
\hline \multirow{2}{*}{ Fungal genera } & \multicolumn{2}{|c|}{ Incidence (\%) in maize hybrids } \\
\cline { 2 - 3 } & ZP434 & ZP704 \\
\hline Acremonium & 0.13 & 7.75 \\
\hline Alternaria & 22.63 & 41 \\
\hline Aspergillus & 5.2 & 0.5 \\
\hline Chaetomium & 1.5 & 0 \\
\hline Cladosporium & 0.63 & 0.5 \\
\hline Fusarium & 33.89 & 42 \\
\hline Nigrospora & 0 & 2 \\
\hline Penicillium & 3.88 & 1.75 \\
\hline Rhizopus & 31.63 & 4.5 \\
\hline Trichotecium & 0.13 & 0 \\
\hline
\end{tabular}

$F$. verticillioides was the most common species among the identified Fusarium species in both examined hybrids and their presence ranged from $28.6 \%$ (ZP434) to $30.5 \%$ (ZP704). F. proliferatum and $F$. subglutinans were classlessness in the hybrid ZP704 (7\% and 1.50\%) compared to the hybrid ZP434 (0.13\%), while the species $F$. graminearum was classlessness in the hybrid ZP434 (5\%) compared to the hybrid ZP704 (3\%) (Table 2).

Table 2. Incidence* (\%) of Fusarium spp. on grains in two maize hybrids

\begin{tabular}{|l|c|c|}
\hline \multirow{2}{*}{ Fusarium spp. } & \multicolumn{2}{|c|}{ Incidence (\%) in maize hybrids } \\
\cline { 2 - 3 } & ZP434 & ZP704 \\
\hline Fusarium graminearum & 5 & 3 \\
\hline Fusarium proliferatum & 0.13 & 7 \\
\hline Fusarium subglutinans & 0.13 & 1.5 \\
\hline Fusarium verticillioides & 28.63 & 30.5 \\
\hline
\end{tabular}

*Calculated in relation to the total number of isolated fungi.

\section{Discussion}

The quality of livestock feed is required for the maintenance of physiological function and the defence of animals against the disease. Based on the analysis of certain components of feeds, an overall quality can be assessed. In this paper 
microbiological quality testing of medium early and late maturity maize hybrids established the presence of pathogenic fungal species from 10 genera. Fusarium species known as economic very important toxigenic species were the most present.

Out of four isolated Fusarium species, F. verticilliodes was the most common in both hybrids, followed by $F$. graminearum, while the species of $F$. proliferatum (Matsushima) Nirenberg and F. subglutinans were less present. This is in agreement with data presented by Logrieco et al. (1995). According to these data the $F$. verticilliodes and $F$. graminearum species in the Mediterranean countries were most frequently isolated from maize. Fusarium species commonly isolated from Mediterranean cereals produce high amounts of fumonisin $\mathrm{FB}_{1}$ and zearalenone $(\mathrm{ZON})$ in vitro on different media. A study of $\mathrm{FB}_{1}$ production by 28 strains of $F$. verticillioides isolated from cereals in Italy, Spain and France revealed fumonisinotoxigenic potential for all strains with a maximum produced concentration of $4100 \mu \mathrm{g} \mathrm{g}^{-1}$ (Visconti and Doko, 1994).

The results obtained in the period 1994-1996 by Lević et al. (1997) indicate that $F$. verticillioides $(63.0 \%)$ is predominant maize ear rot pathogen in Serbia, followed by the $F$. subglutinans $(50.6 \%), F$. graminearum $(12.2 \%), F$. proliferatum (9.6\%) and F. oxysporum Schlech. (5.8\%). According to these authors, F. solani (Mart.) Appel \& Wollen. occurred each year during the stated period, but its frequency was not so high (2.4\%), and other Fusarium species (F. equiseti, F. sporotrichiodes, $F$. chlamydosporum, $F$. crookwellense and $F$. semitectum) occurred sporadically on a few number of samples.

In Canada, according to Xue et al. (1995), F. subglutinans was a dominant species recovered from $28.8 \%$ of the silage maize grains and its incidence increased with delayed harvesting time. The other Fusarium species were also isolated: $F$. oxysporum $(2.6 \%), F$. graminearum $(2.5 \%), F$. proliferatum $(0.3 \%)$ and $F$. sporotrichioides $(0.2 \%)$. These authors observed four silage maize hybrids and established a significantly lower occurrence of Fusarium species in the hybrid NK BRAND Enefrast 1 than in other tested hybrids (MAIZEX leafy 4, Pioneer 37M81 and MYCOGEN TMF94). In addition, they found a significant presence of Fusarium species in all investigated hybrids after late harvest. In our tests we found a significant presence of Fusarium species in the hybrid belonging to later maturity group with a higher percentage of grain moisture $(22.00 \%)$ than in the hybrid belonging to medium maturity group and with a lower percentage of grain moisture $(16.31 \%)$.

\section{Conclusion}

Microbiological analyses of maize grains, intended for silage, show that a small number of grains of investigated hybrids were not contaminated with fungi 
(up to $0.38 \%$ ). The presence of 10 fungal species was determined on the collected samples. Fusarium, Alternaria and Rhizopus were predominant species. F. verticilliodes was the most dominant Fusarium species and was followed by $F$. graminearum, $F$. proliferatum and $F$. subglutinans.

Based on these results it can be concluded that the incidence of individual fungi was higher in the late grain hybrid with a higher moisture content than in the medium-early hybrid with a lower moisture content. Furthermore, these results indicate that investigated samples, due to the presence of toxigenic fungi in high percentage (up to $40 \%$ ), are not safe for animal feeding.

\section{Acknowledgment}

Research was financed by the Ministry of Education and Science, Republic of Serbia project, TR-31023.

\section{Pojava Fusarium vrsta u zrnu kukuruza za silažu}

V. Krnjaja, J. Lević, S. Stanković, Z. Bijelić, V. Mandić, Lj. Stojanović

\section{Rezime}

Uzorci zrna dva hibrida kukuruza, srednje rani (ZP434) i kasni (ZP704), sakupljeni su u vreme berbe 2008. godine i analizirani na kontaminiranost gljivama. Zrna kukuruza zasejana su na hranljivu podlogu i razvijene gljive identifikovane su na osnovu morfoloških, makroskopskih i mikroskopskih osobina na krompirdekstroznoj (PDA) i sintetičkoj hranljivoj podlozi (SNA). Kod oba ispitivana hibrida vrste roda Fusarium su bile najzastupljenije sa prisustvom od 33,89\% (ZP434) do 42\% (ZP704). Ostali rodovi gljiva, Acremonium, Alternaria, Aspergillus, Chaetomium, Cladosporium, Mucor, Nigrospora, Penicillium, and Trichotecium, izolovani su od 0 do $41 \%$. U rodu Fusarium identifikovane su četiri vrste, od kojih je vrsta $F$. verticillioides bila najzastupljenija sa $28,63 \%$ kod hibrida ZP434 i 30,5\% kod hibrida ZP704. Vrsta $F$. graminearum bila je prisutna od 3\% (ZP704) do 5\% (ZP434), F proliferatum od 0,13\% (ZP434) do 7\% (ZP704) i $F$. Subglutinans od 0,13\% (ZP434) do 1,5\% (ZP704). Uopšteno, ustanovljena je značajnija pojava svake pojedinačne vrste gljive kod kasnog hibrida sa višim sadržajem vlage u zrnu, nego kod srednje ranih hibrida sa nižim sadržajem vlage u zrnu. 


\section{References}

BURGESS L.W., SUMMERELL B.A., BULLOCK S., GOTT K.P., BACKHOUSE D. (1994): Laboratory manual for Fusarium research. Fusarium Research Laboratory, Department of Crop Sciences, University of Sydney and Royal Botanic Gardens, Sydney, 133 p.

ELLISS M.B. (1971): Dematiaceous Hyphomycetes. Commonwealth Mycological Institute, Kew, Surrey, England, 608 p.

JAKIĆ-DIMIĆ D., NEŠIĆ K., PETROVIĆ M. (2009): Mycotoxins in feed for pigs and poultry. Biotechnology in Animal Husbandry, 25, 5-6, 1149-1154.

LEVIĆ J., STANKOVIĆ S., BOČAROV-STANČIĆ A., ŠKRINJAR M., MAŠIĆ Z. (2004): Overview on toxigenic fungi and mycotoxins in Serbia and Montenegro. In: LOGRIECO A., VISCONTI A. (eds), An overview on toxigenic fungi and mycotoxins in Europe. Kluwer Academic Publishers, The Netherlands, 201-218.

LEVIĆ J., TAMBURIĆ-ILINČIĆ LJ., PETROVIĆ T. (1997): Maize kernel infection by Fusarium species in the period 1994-1996. Cereal Research Communications, 25, 3, 773-775.

LOGRIECO A., MORETTI A., RITIENI A., BOTTALICO A., CORDA P. (1995): Occurence and toxigenicity of Fusarium proliferatum from preharvest maize ear rot and associated mycotoxins in Italy. Plant Dis., 79, 7, 727-731.

NELSON P.E., TOUSSOUN T.A., MARASAS W.F.O. (1983): Fusarium species, an illustrated manual for identification. The Pennsylvania State University Press, University Park and London, 193 p.

SCUDAMORE K.A. (1993): Mycotoxins in stored products: Myth or menace. Int. Biodeter. Biodegr. 32, 191-203.

STATISTIČKI GODIŠNJAK SRBIJE/STATISTICAL YEARBOOK OF SERBIA (2009): Republika Srbija. Republički Zavod za statistiku, Beograd, 489 p.

VISCONTI A., DOKO M.B. (1994): Survey of fumonisin production by Fusarium isolated from cereals in Europe. J. Assoc. Offic. Anal. Chem., 77, 546-550.

XUE A.G., MA B.L., CLEAR R.M., VIGIER B.J. (2005): Effect of time of harvest on the incidence of Fusarium spp. in kernels of silage corn. Phytoprotection, 86, 3, 189-194.

WATANABE T. (1994): Pictorial atlas of soil and seed fungi. In: Morphologies of cultured fungi and key to species. Lewis Publishers, Boca Raton, Boston, London, Washington D.C., $410 \mathrm{p}$.

WHITE D.G. (1999): Compendium of corn diseases. Third Edition. APS Press, $410 \mathrm{p}$. 